\title{
Characterizing seasonal fishing patterns and growth dynamics during the Middle and Late Holocene in the Strait of Magellan (Chilean Patagonia): Sclerochronological analysis of tadpole codling (Salilota australis) vertebrae
}

\author{
Torres Jimena ${ }^{1,{ }^{*}}$, Mahe Kelig ${ }^{2}$, Dufour Jean-Louis ${ }^{2}$, Bearez Philippe ${ }^{3}$, San Roman $M^{1}$
}

1 Instituto de la Patagonia, Universidad de Magallanes, Chile

2 IFREMER, Fisheries laboratory, Sclerochronology Centre, France.

${ }^{3}$ MNHN, CNRS UMR 7209, France.

* Corresponding author : Jimena Torres, email address : Jimena.torres@umag.cl

\begin{abstract}
:
We describe sclerochronological analyses of tadpole codling (Salilota australis) vertebrae as a proxy for the seasonal timing of fishing activities at one Middle Holocene (6500 BP) and three Late-Middle Holocene (3500-2500 years BP) archaeological sites located in Seno Otway and in the central zone of the Strait of Magellan, Chile. These data were also used to provide an approximation of the population characteristics of the species in the past, by estimating the relationship between size and age of the archaeological fish and comparing their growth rate to those of modern specimens, captured monthly over one year. The results showed that the size at age was significantly larger in archaeological samples than in the modern reference collection. Our results indicate that fishing activities took place throughout the year at the Late Holocene sites, with a special emphasis on the cold season, while the Middle Holocene site showed a tendency to catch tadpole codling during the warm season.
\end{abstract}

Keywords: Patagonia, prehistoric fishing, sclerochronology, seasonality, ichthyoarchaeology, fish growth 


\section{Introduction}

Along the South American Pacific Coast, fishing activity played a preponderant role in the economies of prehistoric, historical and present-day societies, partly sustained by the high marine productivity generated by upwelling ecosystems and the Humboldt Current (Montecino and Lange 2009; Salvatteci et al. 2018). From the Middle Holocene onwards, an intensification of fishing activity has been clearly and repeatedly identified along the coast of South America, mainly targeting pelagic fishes, such as anchovy (Engraulis ringens) in Peru (Béarez and Miranda 2000, Sandweiss 2001; Sandweiss et al. 2009; Reitz and Sandweiss 2001; Reitz et al. 2008), jack mackerel (Trachurus murphyi) and snoek (Thyrsites atun) on the Chilean northern coast (Béarez et al. 2016, Olguín et al. 2014, Rebolledo et al. 2016, Salazar et al. 2017) and the southern coast (Gaete et al. 2004; Quiroz et al. 2000; Quiroz et al. 2001; Vargas 2008). During the Late Holocene, occupations where fishing was the focus of activity multiplied, and extended even further south into what is now southern Chile (Gaete et al. 1998; Munita 2017; Quiroz and Sánchez 2000; Seguel 1998; Torres et al. 2007) as well as the northern and central archipelagos of Patagonia (Legoupil et al. 2007).

In the southern archipelagos of Patagonia, the environmental setting changes significantly. Oceanographic dynamics are linked to the Antarctic ecosystem through the Antarctic Circumpolar Current (Antezana 1999). Particularly in the Strait of Magellan, the oceanography and ecology vary from east to west, and along a latitudinal gradient, being influenced by both Atlantic and Pacific Oceans. In this context, and considering paleoecologic and paleoceanographic variation in the region (Aracena et al. 2015; Caniupán et al. 2014; Harada et. al. 2013; Kilian and Lamy 2012; McCulloch and Davies 2001), marine hunter-gatherers, from as early as the Middle Holocene (ca. 6500-5000 yrs BP) clearly possessed the necessary navigation skills to enable them to move 
between fjords and inland seas. Although specialized in marine hunting (Emperaire and Laming 1961; Legoupil 1997; Ortiz Troncoso 1979; San Román et al. 2016), fishing also played a significant role during this period. The presence of ichthyoarchaeological remains and fishing artifacts from all the sites, represented by lithic weights probably used to sink fishing lines (Emperaire and Laming 1961; Legoupil 1997; Torres 2007; Torres and Ruz 2011), indicate the importance of fishing. In the region, these activities were centered on demersal species, which live near rocky bottoms, in particular the tadpole codling (Salilota australis), which dominate archaeological remains examined from middens. It seems, therefore, that the importance of fishing was similar to that of the hunting of birds and marine mammals (Morello et al. 2012; San Román et al. 2016).

The importance of fishing for demersal species, along with hunting of birds, increased in the region between 3500 and 2500 yrs BP (Legoupil et al. 2011a; Morello et al. 2012; San Román et al. 2016; Torres 2016). This observation is based on the relative contribution of fish compared to other vertebrate fauna, where tadpole codling dominate remains. In turn, this raises the question as to whether the increase reflects an increased focus and specialization on the exploitation of tadpole codling, as was the case in the north of the Beagle Channel after 1500 yrs BP (Zangrando 2009 a-b), or alternatively, whether it reflects other factors such as the over-representation of fishing sites in the sector under study, and sites based on the exploitation of alternative resources might be located in other geographical locations (e.g. the Occidental archipelagos of the Strait of Magellan).

A further question arises as to what extent changes in the population structure of tadpole codling, and their abundance and accessibility 3500 years ago may have influenced the increased importance in the human diet. It is important to note that the importance of demersal fishing decreased significantly after 2000 yrs BP in the Strait of Magellan. As such, the increased 
contribution of tadpole codling only characterizes the period between 6500 and $2500 \mathrm{yrs} \mathrm{BP}$ (Torres 2016).

Here, using sclerochronological analyses of tadpole codling vertebrae, we attempt to provide an approximation of the seasonality of fishing activities and settlement at the study sites. We also aim to examine the extent to which the interpretation of the degree of intensity of fishing activity may have been influenced by seasonal occupational redundancy. For example, summer fishing could be over-represented, since the nutrient availability for the fish increases during this period, as does the accessibility and abundance of tadpole codling in coastal areas. Another possibility is that there were fishing events with a longer permanence during the year, which would have supported a greater occupational intensity and a wider economic importance in fishing for the marine hunter-gatherer populations in the region. This study also intends to contribute to the improved understanding of prehistoric seasonal mobility range in the Patagonian archipelagos, considering the scarcity of seasonality indicators. Indeed, there are generally more signs of summer or spring season activities than for winter activities. For example, migratory birds and neonates of marine mammals generate an imbalance in the assessment of an occupation's permanence and in establishing the seasonality of the settlement.

Finally, this study aims to evaluate changes in key population life history characteristics (age/total length) of tadpole codling in the past, in order to understand whether these characteristics are related to its importance in prehistory.

\section{Area of study}

\section{Current environmental conditions}

The Strait of Magellan (52 $40^{\prime}$ S) separates the South American continent from the island of Tierra del Fuego. It is a long $(583 \mathrm{~km})$ interoceanic channel (Atlantic-Pacific Ocean) that extends from east to west (Figure 1). The rugged bathymetry and geomorphology of the fjords drive the mixing 
of fresh water from the continent with salt water from the sub-Antarctic Pacific Ocean, which in turn is influenced by prevailing southwest winds, precipitation, glaciers, and the melting and tidal currents (González et al. 2013; Harada et al. 2013; Kilian et al. 2007). Likewise, the interaction between the oligotrophic freshwater surface layer and the underlaying nutrient-rich saltwater strongly affect fluctuations in primary production and plankton community structure (Aracena et al. 2015; Iriarte et al. 2018), which also drives seasonal changes in phytoplankton biomass (Iriarte et al. 2001).

The contemporary sea surface temperature (SST) in the central basin of the Strait of Magellan during the spring ranges from between 7 and $7.5^{\circ} \mathrm{C}$ (Valdenegro and Silva 2003): the SST in Punta Arenas $\left(53^{\circ} 10^{\prime} \mathrm{S}\right.$ ) drops to $6.1-8.9^{\circ} \mathrm{C}$ in autumn and $4.6-4.9^{\circ} \mathrm{C}$ in winter (Rojas et al. 2004). Winter temperatures contrast with those recorded in spring $\left(5.4-7.8^{\circ} \mathrm{C}\right)$ and summer $\left(8.8-9.7^{\circ} \mathrm{C}\right)$, especially in spring when they increase and vary more with the bathymetry. Salinity is $30.5 \%$ in the upper layer (which extends to $75 \mathrm{~m}$ ), and gradually increases to $31.5 \%$ below 500 m. In the water column, the upper layer is cold and variable with inverted thermocline and halocline, i.e. temperature and salinity are lower in the upper layer of the water column. This is due to glacial and fluvial contributions, precipitation and glacier melt, which provide fresh, cold water with a high content of dissolved oxygen and low nutrients. Likewise, the action of wind and tidal currents maintains this layer at a low temperature making it more unstable (Valdenegro and Silva 2003). The lower layer, at depth greater than $100 \mathrm{~m}$, has both higher temperature and salinity (Sievers 2008). At these depths, there is a greater contribution from the bodies of water coming from the Pacific Ocean, which is more saline, has a lower content of dissolved oxygen, a lowerpH and higher nutrient concentrations (Valdenegro and Silva 2003). It is also more stable than the surface layer and often becomes homothermal (Sievers 2008). 

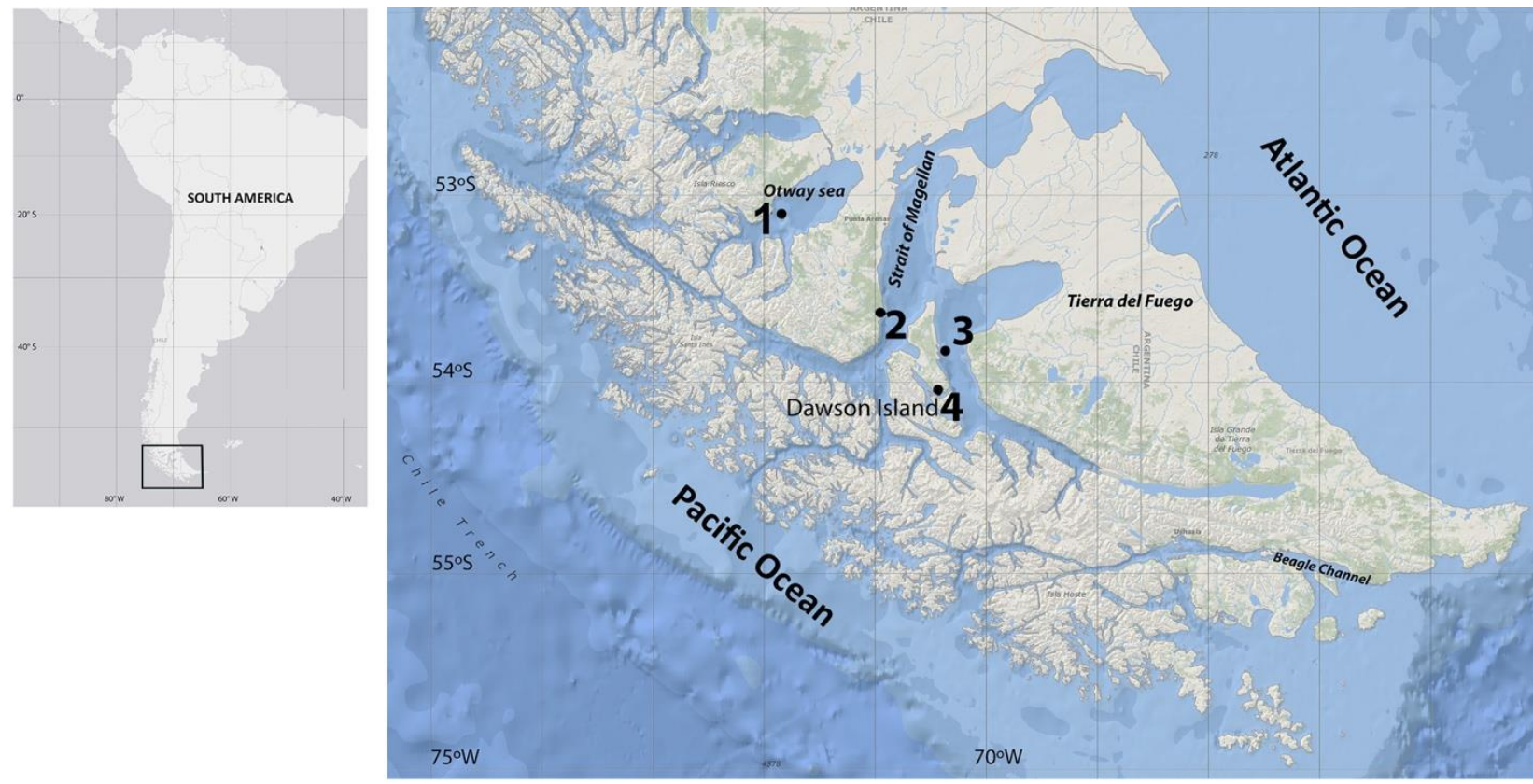

Figure 1. Study area and archaeological sites. 1: Pizzulic 2 (Englefield Island), 2: Punta Santa Ana 2, 3: Offing 2 -locus 1- (Offing Islet), 4: Dawson 3 (Dawson Island).

\section{Paleoceanographic conditions during the Middle and Late Holocene in the Strait of Magellan}

Primary productivity in the Magellan Strait fjord system is mainly influenced by changes in the light regime and influx of fresh water from precipitation and melting glaciers, all of which have a role at different scales of time, both seasonal and millennial (Aracena et al. 2015).

Oceanographic and ecological changes during the Holocene could have influenced the accessibility and abundance of different fishes exploited by hunter-fisher-gatherer societies. Sea surface temperatures remained high in the region during the Middle Holocene, which coincided with an increase in humidity and precipitation (McCulloch and Davies 2001). Some studies report a gradual decrease in temperatures from $6000 \mathrm{BP}$ to the Late Holocene (Harada et al. 2013). A neoglacial period at about 5500/4500 yrs BP has also been suggested, which would have resulted in decreased SSTs (Caniupán et al. 2014). Indeed, SST records for the Late Holocene show that in the fjords and inland seas, as well as in the offshore areas of the Chilean continental margin, there 
was a decrease in SST. Additionally, very pronounced cold events (minus $1{ }^{\circ} \mathrm{C}-2^{\circ} \mathrm{C}$ ) occurred between 600 and 250 yrs BP, and were amplified in the inland seas (Caniupán et al. 2014). Similarly, palaeoceanographic proxies of primary productivity from the central basin of the Strait of Magellan display a sharp decline between 3000 and 2200 yrs BP, with a strong reduction in salinity due to a period of intense freshwater supply, probably caused by higher rainfall and glacial advance. After this period, productivity recovered quickly (Aracena et al. 2015).

\section{Study taxon}

Tadpole codling is a gadiform fish that inhabits the southern tip of South America in waters of subAntarctic origin. It is distributed in the Atlantic from $38^{\circ} \mathrm{S}$ to $56^{\circ} \mathrm{S}$ and in the southeastern Pacific from $40^{\circ} \mathrm{S}$ to $57^{\circ} \mathrm{S}$; its density in the Pacific is lower than in the Atlantic (Avilés and Aguayo 1979). Currently, this species has a greater commercial importance in Argentinian waters (Wöhler et al. 2004; Cassia 2006); however, its commercial importance has also increased in recent years on the Chilean side, in the face of the decline of other demersal target species (Chong et al. 2017).

This bentho-demersal species typically inhabits rocky bottoms, crevices and underwater caves. Typically, tadpole codling inhabit depths of between 50 and $900 \mathrm{~m}$ (Cassia 2006), although they are mainly concentrated between 100 and 200 m (Pérez Comas 1980). They can tolerate a wide range of temperatures between $3^{\circ} \mathrm{C}$ and $13^{\circ} \mathrm{C}$ (Wöhler et al. 2004), although most have been captured in bottom waters with temperatures of between $4^{\circ}$ and $8^{\circ} \mathrm{C}$, throughout the year (Cassia and Hansen 2005).

To feed, tadpole codling undertake vertical migration through the water column, especially in the case of younger adults (Pérez Comas 1980). Juvenile individuals $(<20 \mathrm{~cm})$ are pelagic, but migrate to benthic habitats in deeper waters once this size threshold has been met. When they move vertically they do not move in surface waters (Reyes and Hüne 2012): in the inland seas of the Magallanes region, individuals have been reported from the sublittoral zone (10 to $30 \mathrm{~m}$ deep). In 
this geographical sector, individuals have been observed moving from deep layers during the night (Sielfeld et al. 2006). In general, they are concentrated in waters with a high salinity, and the highest concentrations have been observed in waters with salinities of 33.5 - 33.9 \%o (Pérez Comas 1980).

Regarding migratory behavior, Atlantic Ocean populations move northwards and into increasing depths as winter approaches. In early spring there is a movement of adults in an eastwest direction towards the coast of the Falkland Islands for reproduction (Wöhler et al. 2004). It should also be noted that in winter and spring two groups are formed, one in the northwest of the Falkland Islands and the other in the Patagonian-Fuegian shelf. In summer they disperse widely to the south. In Chile there is an important spawning period between August and September (Chong et al. 2017).

Currently, tadpole codling lives to around 16 years. Females can grow longer than males, reaching a maximum size of $80 \mathrm{~cm}$ total length (TL) compared to $76 \mathrm{~cm}$ TL for males (Wöhler et al. 2004). During their first year, they reach approximately $18.5 \mathrm{~cm}$ TL, reaching maturity at 3-4 years and about $38 \mathrm{~cm}$ (Wöhler et al. 2004).

\section{Methodology}

This study is based on sclerochronology, which aims to estimate age and the rate of growth throughout the life of the fish, and to establish the periods of seasonal growth by using hard structures such as teeth, scales, otoliths and bones. The cyclic growth of these calcified structures is structured by concentric layers deposited at daily and seasonal intervals. Seasonal growth rings are formed by a translucent and an opaque zone, which together constitute an annual ring (annulus); a set of these annuli records the historical growth of the fish from hatching to death.

Generally, studies of contemporary population dynamics or the seasonal cycles of fish growth are based on otoliths and scales (Mahé et al. 2009; Panfili et al. 2002). The same methodology has been used on ichthyoarchaeological samples to answer questions regarding 
paleodemography and population structure of certain important species in prehistoric and historical economies (Guillaud et al. 2017; Van Neer et al. 1999), and also to estimate seasonal patterns of fishing activity (Casteel 1976; Desse and Desse-Berset 1992; Guillaud et al. 2017; Scartascini et al. 2015; Van Neer et al. 1993).

\section{Modern reference collection}

We collected a sample of 69 tadpole codling individuals to act as a modern reference collection. Most fish were captured during 2009, with the sample being complemented in early 2010, December 2012 and August 2013. The specimens representative for a range of commercial fish sizes were collected with longline from the central basin of the Strait of Magellan between Punta Carrera (Brunswick Peninsula) and Dawson Island (Figure 1), the same area where archaeological samples were collected.

All individuals were measured for their total length (TL $\pm 1 \mathrm{~mm}$ ), standard length (SL \pm 1 $\mathrm{mm})$ and total weight $(\mathrm{W} \pm 0.1 \mathrm{~g})$. Vertebrae were used to characterize tadpole codling age and growth due to their abundance and good preservation in the archaeological sites of the study, providing us with a wide sample. The otoliths of the modern collection were also used; however, the archaeological ones were eliminated from this study due to their poor preservation and illegibility of the rings. Likewise, the slight tendency of seasonal growth identified in the otoliths of the modern collection contrasts with the results obtained with both current and archaeological vertebrae.

The left otoliths and the 4th (V4) and 5th (V5) vertebrae of all specimens from the modern collection were analyzed (Table 1). With respect to the archaeological samples, only V4 and V5 were analyzed. These anatomical units were chosen because they were abundant and well preserved, but also displayed diagnostic features that allowed them to be clearly identified in the archaeological record, and enabling us to obtain a minimum number of individuals (MNI). 
Table 1. Total modern sample. 4th vertebra, 5th vertebra and otoliths.

\begin{tabular}{|c|c|c|c|c|c|c|c|c|c|c|c|}
\hline \multirow[b]{2}{*}{ Month } & \multicolumn{3}{|c|}{$\begin{array}{l}\text { Modern Collection } \\
\text { Year } 2009\end{array}$} & \multicolumn{3}{|c|}{ Year 2010} & \multicolumn{3}{|c|}{ Year 2012} & \multicolumn{2}{|c|}{ Year 2013} \\
\hline & V4th & V5th & Otolith & V4th & V5th & Otolith & V4 & V5 & Otolith & V4th & V5th \\
\hline January & & & & 7 & 7 & 8 & & & & & \\
\hline February & 2 & 2 & 2 & 3 & 3 & 3 & & & & & \\
\hline March & 7 & 7 & 7 & & & & & & & & \\
\hline April & 7 & 7 & 7 & & & & & & & & \\
\hline May & 4 & 4 & 5 & & & & & & & & \\
\hline June & 6 & 8 & 7 & & & & & & & & \\
\hline July & 5 & 5 & 4 & & & & & & & & \\
\hline August & & & & & & & & & & 4 & 4 \\
\hline September & 5 & 5 & 4 & & & & & & & & \\
\hline October & 5 & 5 & 4 & & & & & & & & \\
\hline November & 7 & 7 & 6 & & & & & & & & \\
\hline December & & & & & & & 5 & 5 & 5 & & \\
\hline TOTAL & 48 & 50 & 46 & 10 & 10 & 11 & 5 & 5 & 5 & 4 & 4 \\
\hline $4^{\text {th }}$ vertebra & 67 & & & & & & & & & & \\
\hline $5^{\text {th }}$ vertebra & 69 & & & & & & & & & & \\
\hline Otolith & 62 & & & & & & & & & & \\
\hline
\end{tabular}

For the estimation of age and seasonality of capture in tadpole codling, growth rings and their position along the axis between the nucleus (corresponding to the birth date) and the edge (corresponding to the death date) of the calcified parts were identified (Mahé et al. 2009) (Figure 2). The validation process for seasonality corresponds to the marginal increment analysis (MIA, see Beamish \& McFarlane, 1983) according to the following formula: MIA $=\left(R o-r_{n}\right) /\left(r_{n}-r_{n-1}\right)$, where $R o$ is the vertebra or otolith radius, $r_{n}$ is the distance between the edge and the last growth ring, and $r_{n-1}$ is the distance between the edge and the second last growth ring (Figure 2).

Analyzes were carried out at the IFREMER institute in the Sclerochronology Centre (Boulogne-sur-Mer, France). A stereo-microscope with reflected light on a black surface and a digital camera were used to examine structures and to record images. We used a software dedicated to sclerochronology applications (TNPC V. 7) to calibrate and analyze images (Mahé et al. 2011).

We compared v4 and v5 MIA values between the modern warm and cold months (during 1 year with monthly sampling). Increment values were larger (V4 Mann Whitney U = 121, P = 
0.0001; V5 Mann Whitney $\mathrm{U}=195, \mathrm{P}=0.0001$ ) during the warm period -December to June- (V4 median $\pm \mathrm{IQR}=0.86 \pm 0.42 \mathrm{~mm} ; \mathrm{V} 50.75 \pm 0.42)$ than the cold period - July to November- (V4 $0.52 \pm 0.35 \mathrm{~mm}, 0.49 \pm 0.36 \mathrm{~mm})$. Then, using repeated pairwise Mann Whitney tests, we compared the data from modern period with the distribution of MIA values from archaeological samples. Given the number of different comparisons $(\mathrm{n}=16)$ for both V4 and V5, we adjusted the threshold for significance to $P=0.0003$.

\section{Growth modelling}

The growth of tadpole codling was modelled using the von Bertalanffy model (von Bertalanffy, 1938), with $t_{0}$ fixed as 0 :

$$
\square \square_{\square}=\square \square_{\infty}-\left(\mathrm{S} \square_{\infty} \cdot \square^{-\square . \square}\right)
$$

Where $S L_{t}$ and $S L_{\infty}$ are respectively the standard length (SL) at age $t$ and the asymptotic standard length, $K$ the rate at which the asymptote is reached and $t_{0}$ the theoretical age (in years) at zero length. The $t_{0}$ value has no biological significance. Statistical analyses were carried out using the open-source statistical package "R". Likelihood Ratio Tests were used to compare the von Bertalanffy growth curves between different periods (Kimura, 1980). Differences were considered significant for $P<0.05$. 

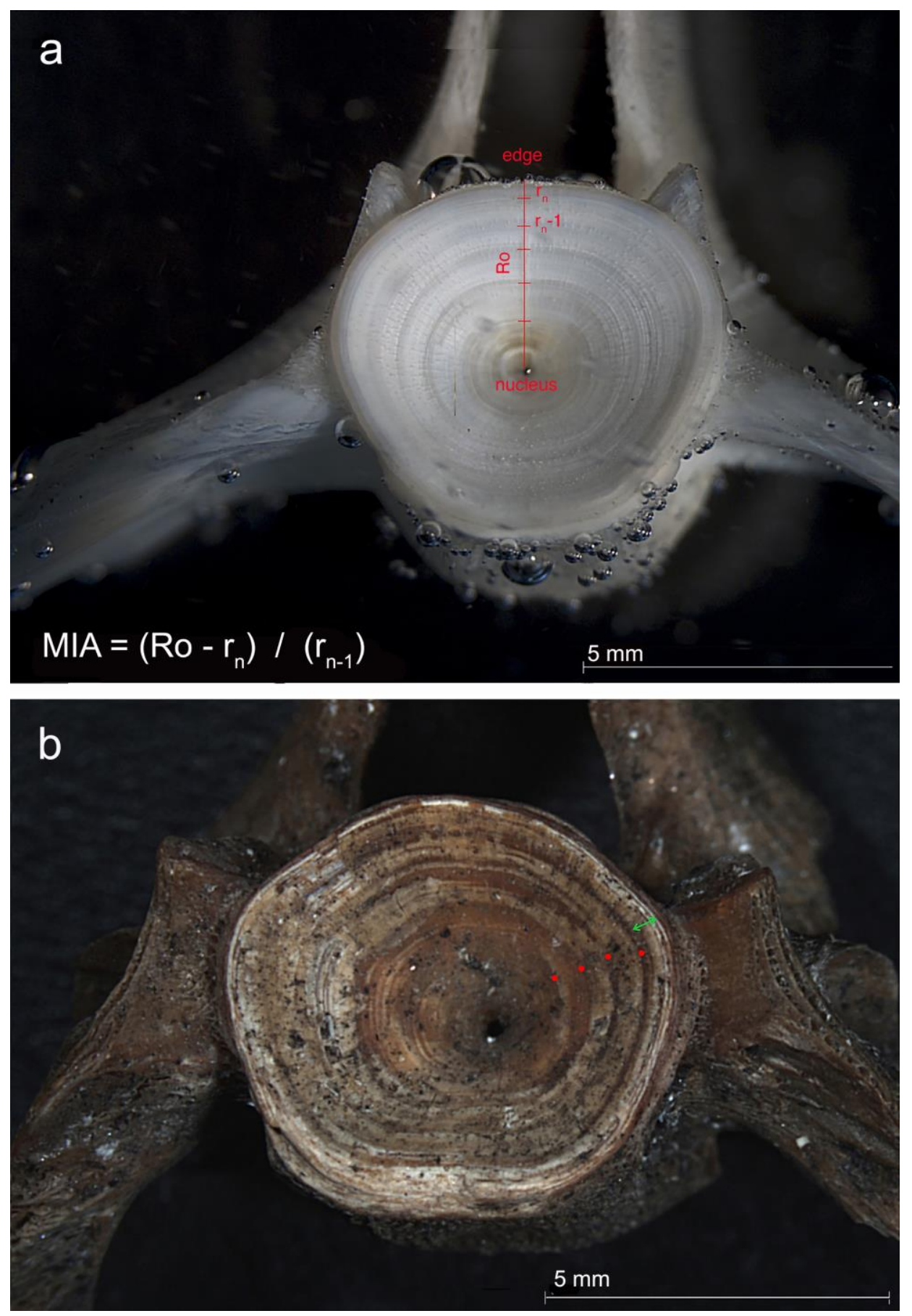

Figure 2. a: 5th modern vertebra (5 years). b: 4th archaeological vertebra (4 years), growth rings (in red) and distance between the last ring and the edge (in green).

Archaeological samples and setting 
Archaeological samples of tadpole codling were collected from three sites dated to between 3500 and 2500 yrs BP, located in the central basin of the Strait of Magellan. The site of Dawson 3 (3090 \pm 56 yrs BP uncalibrated [Erl-10.956]) is located on the southern side of Dawson Island (Legoupil et al. 2011b). It is a shell midden (1 $\mathrm{m}$ deep) containing abundant remains of birds and demersal fish (Legoupil et al. 2011a). At the site of Offing 2 -locus 1- on Offing Island (3020 \pm 20 yrs BP [charcoal, ULA-1068]), $2825 \pm 20$ yrs BP uncalibrated [charcoal, ULA-1066]) there were abundant remains of demersal fish and seabirds in the upper layers, although the remains were more concentrated in the shell midden lower layer. The layer sequences associated with fishing did not exceed 300 yrs of occupational range (Legoupil et al. 2009). The Punta Santa Ana 2 site (3280 \pm 40 yrs BP [shell, Beta-271325] and $3340 \pm 40 \mathrm{yrs}$ BP [shell, Beta-271326] uncalibrated) is located on the continental coast of the Strait of Magellan: samples were collected from a shell midden composed of remains of demersal fish, seabirds and some marine mammals (Morello et al. 2012). Samples of fish vertebrae analyzed to determine seasonality were taken from the most extensive stratigraphic sequence, due to good resolution and thickness, which also contained a large amount of fish remains.

The final site, Pizzulic 2, has a Middle Holocene chronology (5945 \pm 45 yrs BP [Ua-21030] and $6055 \pm 60$ yrs BP [Ua-21031] uncalibrated). It is located on Englefield Island, Seno Otway (San Román 2005), includes technological elements of the Englefield Culture and includes abundant marine mammal remains, as well as fish and birds (San Román 2005).

All the sites examined included single-component shells with stratigraphic continuity and no clear events of abandonment. Furthermore, with the exception of Dawson 3, they have an occupation range of no more than 300 years, which allows for analysis of samples from a limited time period (San Román et al. 2016). We analyzed a total of 255 archaeological vertebrae samples, of which 108 were 4th vertebrae and 147 were 5th vertebrae (Table 2). 
Table 2. Archaeological samples.

\begin{tabular}{|c|c|c|c|c|}
\hline Vertebra & Pizzulic-2 Punta Santa Ana 2 & Offing 2 & Dawson 3 & Total \\
\hline V4 & 9 & 88 & 11 & 108 \\
\hline V5 & 14 & 70 & 18 & 147 \\
\hline Total & 45 & 158 & 29 & 255 \\
\hline
\end{tabular}

\section{Results}

\section{Modern collection}

On average, V5 vertebral radii were larger by $0.32 \mathrm{~mm}$ than in V4 vertebrae (Paired t-test: $t_{66}=9.9, P<0.001$ ), but there was a strong positive relationship between V5 and V4 radii (Figure 3a: Least squares regression $\left.R^{2}=0.78, F_{1,65}=12.25, P<0.001\right)$.

Comparisons of the relationships between fish standard length at capture and the radius of the 4th and 5th vertebrae were made using ANCOVA. The SL-radius relationship had a similar slope (ANCOVA slope: $\mathrm{F} 1,132=9.47, P=0.449$, but the intercept term differed (ANCOVA $_{\text {intercept: }}$ : $\mathrm{F} 1,133=16.42, P<0.001$ ), reflecting the smaller radii for a given fish length (see above). As such, we calculated separate linear regressions for the relationship between fish standard length and vertebral radius for V4 and V5 vertebrae, in order to allow back calculation of fish length e.g. from archaeological samples (Figure 3b). Each regression had comparable statistical characteristics (SLV4: $R^{2}=0.58, F_{1,65}=92.1, P<0.001 ;$ SL-V5: $\left.R^{2}=0.60, F_{1,67}=102.5, P<0.001\right)$, indicating that they have comparable capacity as a means of reconstructing fish length.

The relationship between fish standard length and estimated age at capture was identical for both V4 and V5 vertebrae (ANCOVA slope: $F_{1,132}=0.09, P=0.76$; ANCOVA $_{\text {intercept }} F_{1,133}=$ $0.04, P=0.84$ ), with a positive, but noisy relationship (Figure $3 \mathrm{c}: R^{2}=0.49, F_{1,134}=129.5, P<$ 0.001). All individuals over $30 \mathrm{~cm}$ SL had estimated ages between 4 and 6 years. SL was between $40 \mathrm{~cm}$ and $50 \mathrm{~cm}$ for individuals with estimated ages of 7 and 8 years, and at 9 years of age, specimens measured between $40 \mathrm{~cm}$ and $60 \mathrm{~cm}$ SL. 

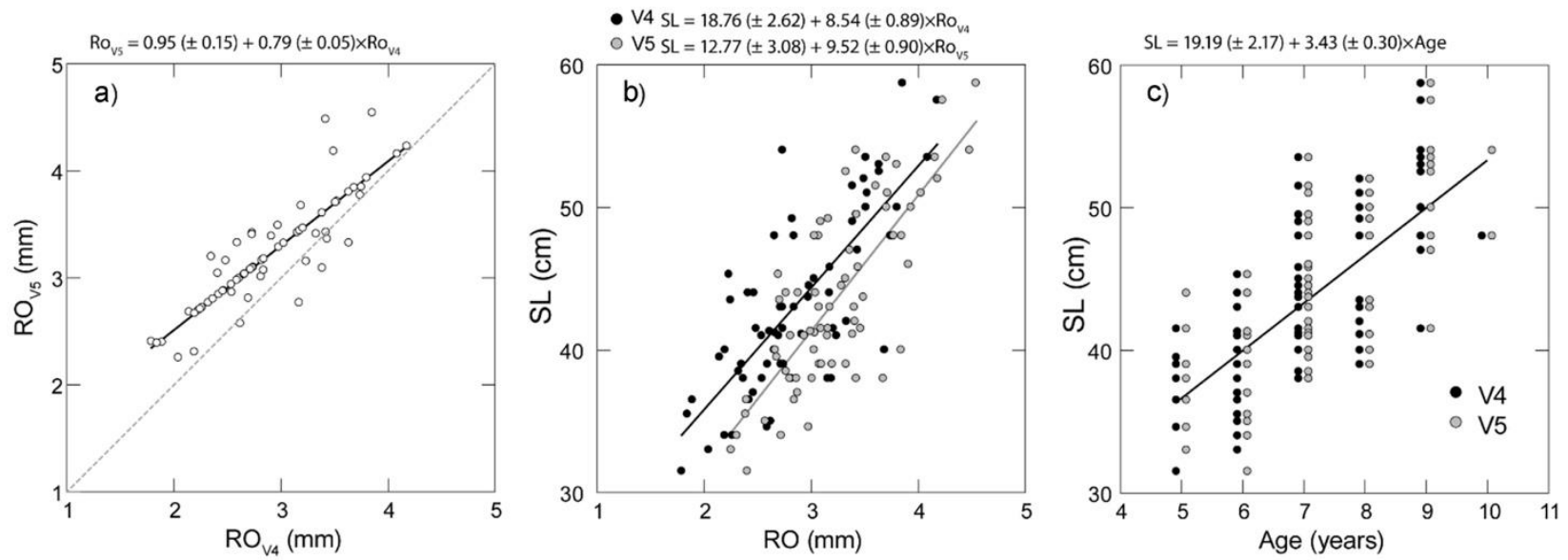

Figure 3. Least squares regressions showing: a) relationship between vertebral radius measurements for V5 and V4, including regression coefficients ( \pm SE). b) Relationships between standard length (SL) and vertebral radius measurements for the two vertebrae. c) The common relationship between fish length and estimated age at capture (n.b. markers have been shifted slightly to reduce overlap).

\section{Modern seasonal model}

Modern tadpole codling had a tendency to increase the marginal increment (MIA) of the vertebrae in austral summer months, which was maintained through to autumn, i.e. from March to June. Lowest MIA values were seen in the winter months, and gradually increased at the end of spring (December: Figure 4).
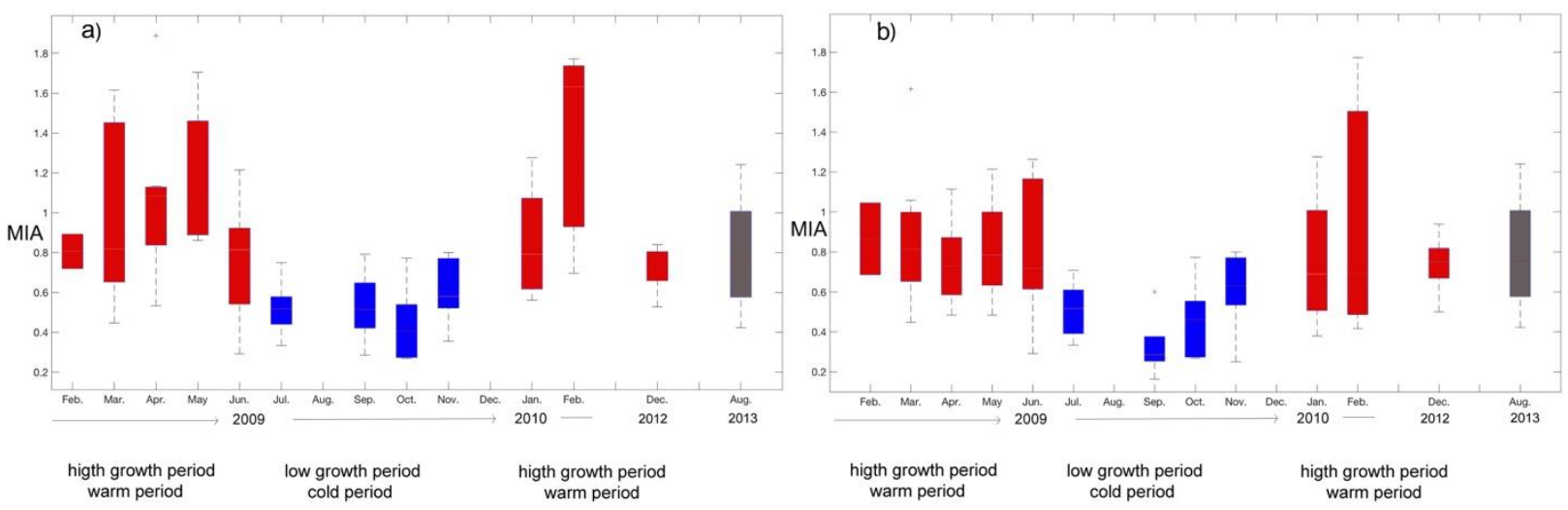
Figure 4. Seasonal growth model of tadpole codling according to the reference collection of the Strait of Magellan. Boxplot of the 4th(a) and 5th (b) vertebra MIA according to the month and year of capture.

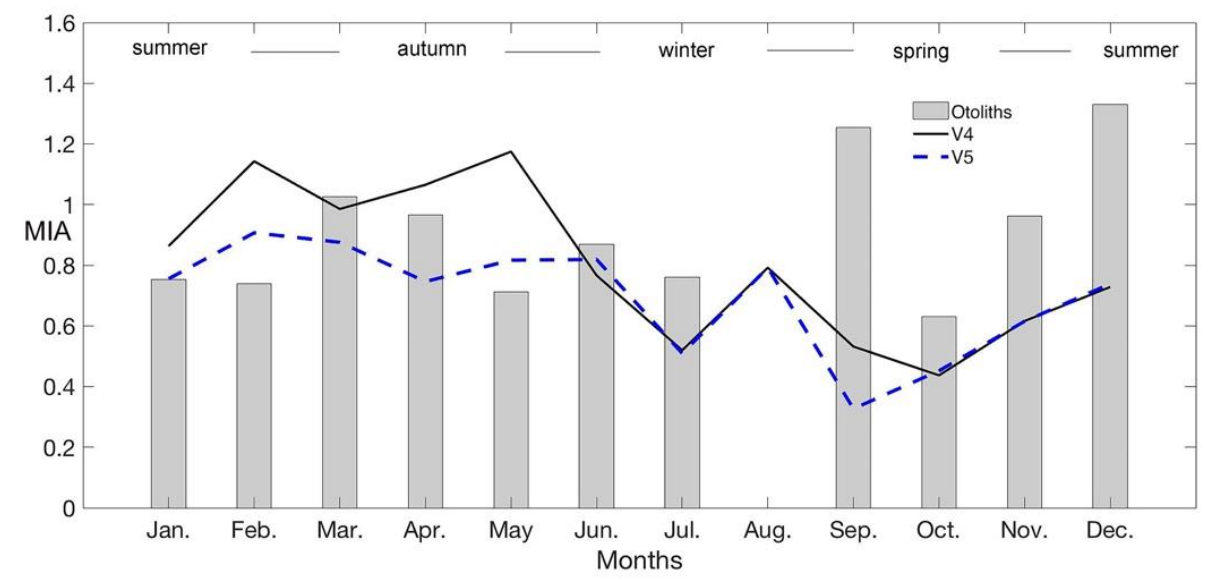

Figure 5. Synthetic seasonal growth model of tadpole codling according to a reference collection in the Strait of Magellan. Comparison between the mean MIA of the otoliths, 4th and 5th vertebra by month of capture.

The MIA ranges for December 2012 showed a similar trend to that observed between 2009 and the summer of 2010; however, samples collected in August 2013 (austral winter) showed a marked increase in MIA values, which were comparable with summer values. This result was considered with caution, as samples were not continually collected throughout 2013.

MIA values calculated from the 4th and 5th vertebrae showed generally similar results (Figures 4-5). Otoliths results were less clear, due to the interpretation difficulty of growth rings in these structures (Figure 5). Due to the lack of precision of the results obtained from the otoliths, we have only included the study of archaeological vertebrae. In order to present the results in a synthetic and clear way, and to have a better appreciation in relation to the archaeological results, modern data were grouped into two seasonal blocks: one representing the warm period (summer- 
autumn) and the other the cold period (winter-spring). Results from August 2013 were not included, as they were temporally distant from the other samples and diverge from the general trend observed from earlier data.

We then used the seasonal patterns observed in MIA values from modern tadpole codling to estimate the likely time of capture in individuals from archaeological samples.

\section{Seasonal fishing in archaeological sites}

Offing 2 -locus 1 -

Figure 6 shows the variation in MIA values shown by individual fish from the Offing 2 site, based on artificial level and following the stratigraphic units. Comparison of MIA values in archaeological fish with results from fish captured during modern warm and cold periods suggest that archaeological fish were captured throughout the year. There was no apparent major difference in results based on either the 4th or 5th vertebrae (Figure 6). The largest number of samples analyzed was from levels 4 and 5 of the shell midden, the layer with the highest density of ichthyoarchaeological remains. This implies archaeological fishing events in the midden occurred mainly in the cold period of the year, according to the 4th vertebra, that is between winter and spring. 

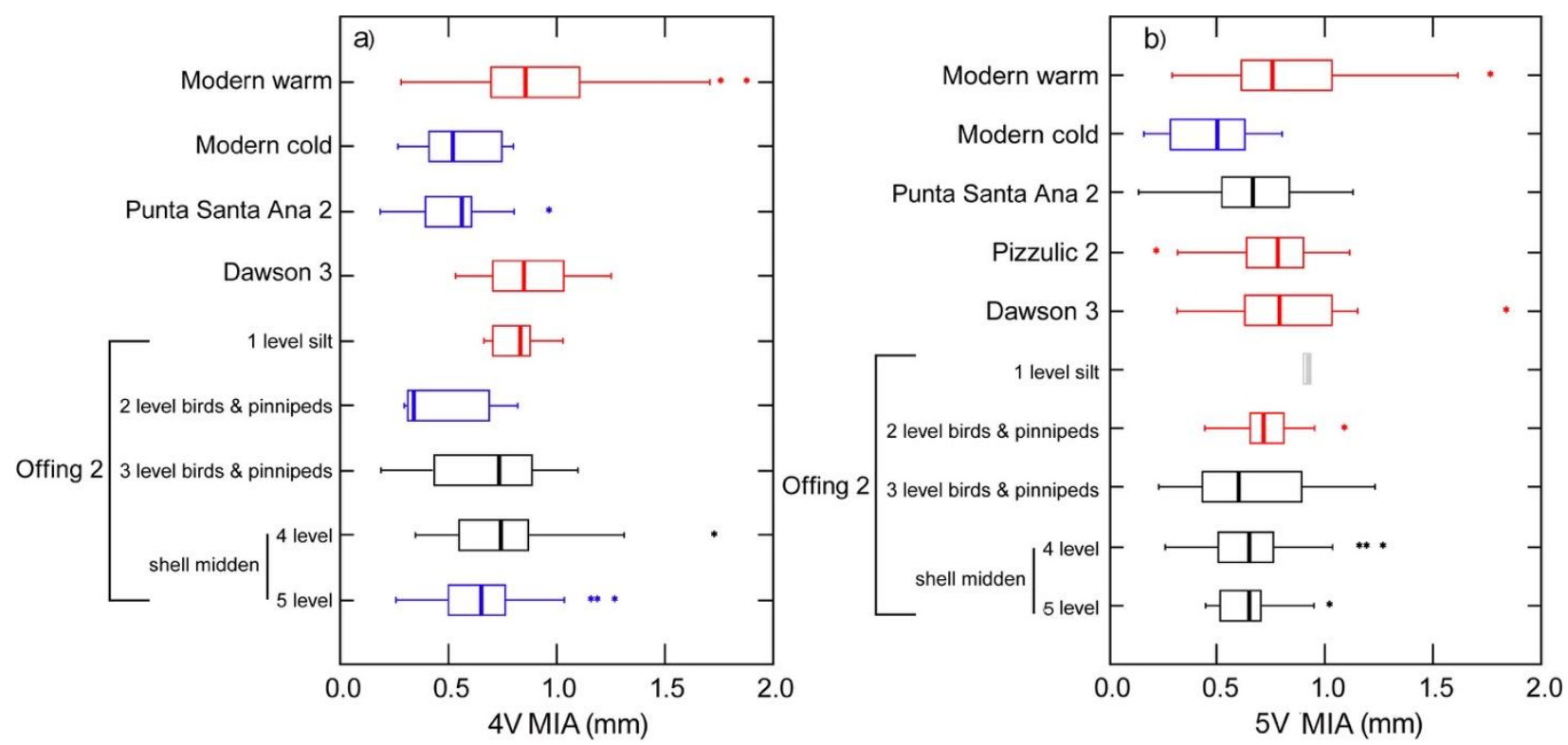

Figure 6. Boxplot showing variation in a) $4 \mathrm{~V}$ and b) $5 \mathrm{~V}$ marginal increment (MIA) values from modern samples of tadpole codling collected during warm and cold periods with samples from different archaeological origins. Data are color-coded to reflect statistical overlap between archaeological samples and modern growth periods using Mann Whitney tests (adjusted for multiple comparisons), with red representing data that are statistically similar to the modern warm growth period, blue for those that are similar to the modern cold period and black for samples that overlap with both modern seasonal periods. Grey values represent a situation where $\mathrm{n}<3$ and no statistical comparison was possible. Boxes show interquartile range (IQR), and the vertical bold line the median value. Whiskers indicate a $1.5 \mathrm{x}$ IQR limit, while asterisks indicate values that are more than $3 \times$ the IQR.

\section{Dawson 3}

Individuals examined from Dawson 3 mostly showed high MIA values, indicating that they were likely captured during the warm period -summer and/or autumn- (Figure 6), with little likelihood that they were captured during the cold period. Stratigraphically, there were no variations in MIA values. 
With regard to other seasonally-indicative indices, juvenile seabirds made a large contribution to the remains (27\% NISP), indicating occupational events between November and March, i.e. the spring-summer period (Legoupil et al. 2011a).

\section{Punta Santa Ana 2}

MIA values were low at Punta Santa Ana 2, indicating that fishing activities were concentrated during cold period -winter and/or spring-.

The duration of site formation at Punta Santa Ana 2 was short and extended to no more than 140 years, (Morello et al. 2012). Similarly, there was no trend in the concentration of low MIA vertebrae in certain sectors or in deep layers of the deposit. One alternative is that the camp had sporadic and repeated occupations between winter and spring. Another alternative is that it was a semi-permanent occupation during several months of the year, especially concentrated during the cold season. A further indicator of seasonality at the site is the presence of Patagonian grenadier (Macruronus magellanicus). This species currently enters this sector of the Strait of Magellan coast during the summer months; however, these remains are scarce. In contrast, another species that was more abundant at the site is the Southern hake (Merluccius sp.), which migrates into this area during spring-summer months. It should be noted however, that fish behavior and distributions may have undergone changes since the Late Holocene as a result of environmental changes: as such these apparent indicators of seasonality should be considered with care.

\section{Pizzulic 2}

Tadpole codling MIA values from Pizzulic 2 indicated that fish were largely captured during the warm season (summer-autumn) (Figure 6). There were no major differences in results from different stratigraphic layers, with the exception of the humus layer. However, samples from this layer were scarce: of the three vertebrae encountered, only one displayed a low MIA value. 
It is important to mention that the formation times of the archaeological deposit were relatively short, around 300 years. The stratigraphy did not show any hiatus or change, suggesting long periods of abandonment between each occupation (San Román 2005). There were no major differences in the stratigraphic distribution of individuals. Similarly, no differences were found in the taxonomic diversity or in the size structures of tadpole codling (Torres 2016).

\section{Changes in the growth of tadpole codling}

Our results indicate that tadpole codling growth has undergone considerable changes in the last 2500 years of the Late Holocene. The range of ages for modern collection and archaeological periods were comparable from 2 years to 12 years. A significant difference in length-at-age data derived from the growth model was found between modern period and both archaeological periods (likelihood ratio test: $\mathrm{p}=0.019)$. There was no significant difference between both archaeological periods (likelihood ratio test: $\mathrm{p}=0.087$ ) (Figure 7). Archaeological tadpole codling were larger at a given age and had a greater mean asymptotic length $\left(\mathrm{SL}_{\mathrm{inf}}=135 \mathrm{~cm}\right)$ than those from the modern reference collection $(69 \mathrm{~cm})$, as well as contemporary Atlantic populations described by Cassia (2006). 


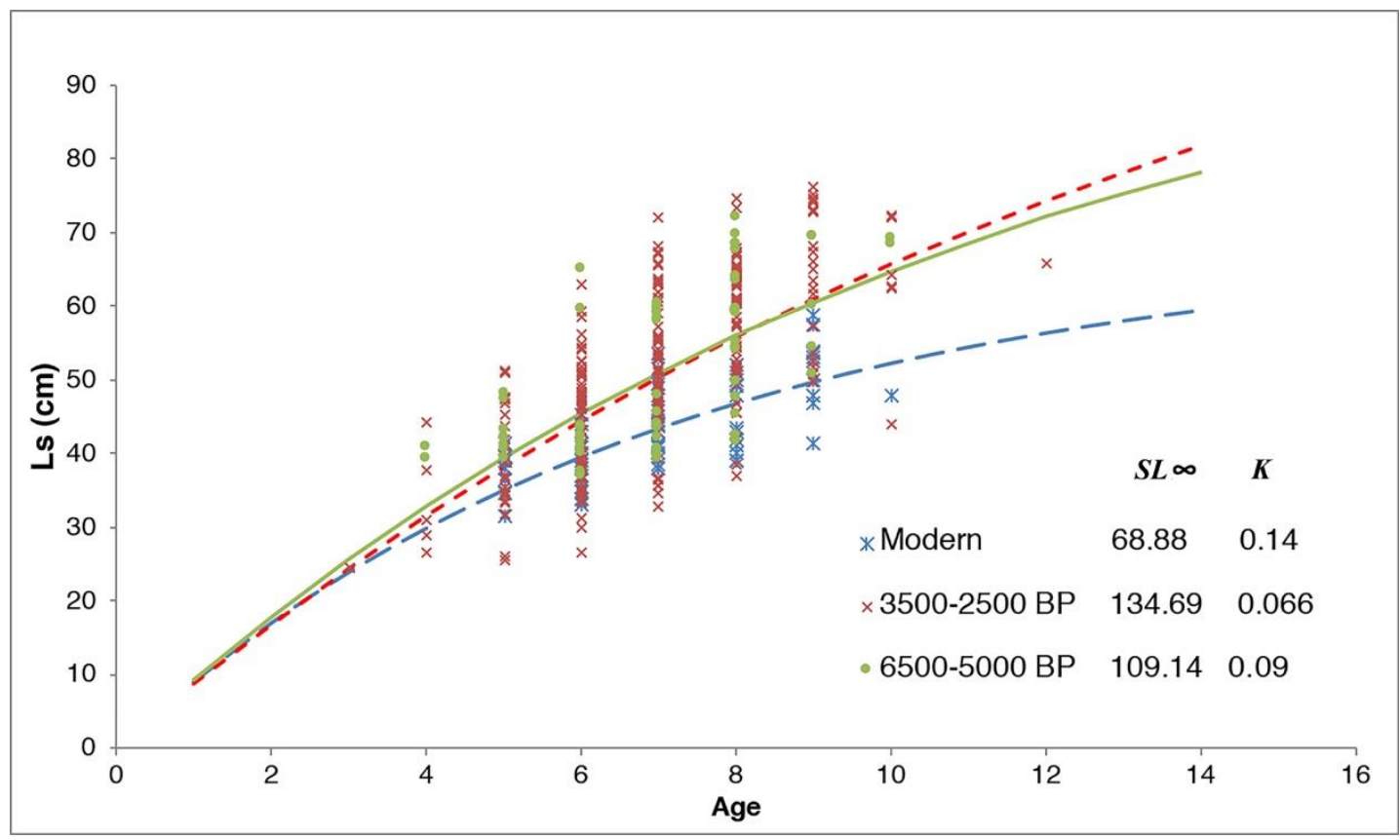

Figure 7. Von Bertalanffy growth model of the populations of modern and archaeological individuals of tadpole codling (Modern sample $=69,3500-2500$ yrs BP sample $=108,6500-5000$ yrs BP sample $=40)$.

\section{Discussion and final considerations}

This study has provided a useful indication regarding the feasibility of using archaeological fish vertebrae as proxies for the period and intensity of seasonal exploitation providing information on the mobility ranges of hunter-fisher-gatherers who inhabited the Magallanes region between 6500 and 2500 yrs BP (uncalibrated). Our model, based on the marginal increment analysis, the condition of the edge as well as the size of the zone in active growth, if the latter is in the process of formation, makes it possible to estimate the period-of-death of tadpole codling. The development of a modern reference collection allowed us to attain readable results with both vertebrae examined (4th and 5th); however, the 4th vertebra showed clearer trends and better archaeological preservation. The seasonal trend in growth was clear in both cases, so the interpretation of the archaeological samples is favorable. 
In addition, the seasonal growth pattern of the modern tadpole codling showed the same trend with the average seasonal water surface temperature in the Strait of Magellan (Punta Arenas) (Rojas et al. 2004). Consequently the growth of tadpole codling could be influenced by the temperature effect as the seasonal results of tadpole codling in the Atlantic Ocean based on the study of otoliths and the presence of a hyaline and opaque rings on the edge indicate (Cassia 2006). Water temperature is an important environmental factor, especially for aquatic ectotherms such as fish (Brett 1971). Temperature affects the growth of fish through direct effects (i.e. metabolism) and indirect effects (i.e. relationship with biotic factors as available food) (Paloheimo and Dickie 1966; Uphoff et al. 2013). Fish experience higher growth rates when their metabolic activity rises with increasing temperature (Brett 1979). In the Strait of Magellan, strong seasonal climatic changes, such as solar radiation and wind, influence the phytoplankton community, which shows significant seasonal changes in biomass and primary productivity, especially during the spring bloom (Iriarte et al. 2001). These changes affect higher trophic levels such as demersal fish.

Regarding the archaeological focus, this study aimed to elucidate whether the large amount of fish remains found at sites in the Strait of Magellan from 6500 to 2500 yrs BP resulted from permanent subsistence activity throughout the year, or reflected a rather seasonal subsistence pattern in the same settlements.

Pizzulic 2 was the only Middle Holocene site, and the results indicate a summer fishery, complemented by the presence of juvenile birds. The results were more conclusive for the Intermediate Period during the Late Holocene (3500-2500 yrs BP). Offing 2 site -locus 1- showed fishing events at different times of the year, with a tendency for fishing events in the cold period (winter-spring). Only in the initial levels and at the bottom of the shell midden (level 5) did there appear to be a higher presence of fish with high growth, implying fishing during the summer season. The role of winter fishing is interesting at this site: at this time of year it is currently more 
difficult to catch this species in shallower waters and near the coast. In these layers there was also an intense and relatively proportional exploitation of birds such as albatross (Diomedea sp.) and petrel (Procellaria sp.) (Lefèvre and Laroulandie 2014). Cormorants (Phalacrocorax sp.) increased their importance in the lower level of the shell midden and in the older levels where there were no fish.

At Dawson 3, fishing was concentrated in the period of average and highest temperatures of the year, and at Punta Santa Ana 2 in the period of colder temperatures. Variations in seasonality may, therefore, be due to differences in site functionality and/or subsistence activities. In the case of Punta Santa Ana 2, bird hunting was oriented towards shearwaters (Puffinus sp.), and then cormorants. In general, the diversity of birds and mammals was low (Morello et al. 2012). The uncommon dominance of shearwaters in the archaeological sites of the Strait of Magellan (except Offing 2- locus 1-) is relevant, as normally cormorants dominate assemblages in the region. In the case of Dawson 3, shearwater was not recorded and bird hunting was oriented towards cormorants, then Anatidae (geese and ducks) and albatross (Legoupil et al. 2011a). At this last site, the richness of birds increased slightly and the representations of taxa were more equitable than in Punta Santa Ana 2. An important fact regarding Dawson Island is the high presence of bird exploitation camps and the presence of juveniles at almost all the sites (Legoupil et al. 2011a), which are normally only present during spring-summer.

The continuity of fishing activity throughout the year in the central zone of the Strait of Magellan has many possible explanations. It could, for example, indicate the distribution, abundance and accessibility that demersal fish communities had during this cultural period, which is reinforced by the rapid growth of tadpole codling during this period. In comparison with the growth parameters shown by the modern reference collection specimens, the samples from the Early (6500 yrs BP) and Intermediate Period (3500-2500 yrs BP) showed greater length at age and 
mean asymptotic lengths. In this last period there is significant faster growth than in the modern collection and in the earlier samples that are represented only by PZ-2. However, the results of PZ2 should be considered with caution, since the sample is very small, and they may also account for inter-regional differences between the Seno Otway and the central basin of the Strait of Magellan; in this last area most of the samples studied are concentrated and there is a greater influence of the oceanographic conditions of the Pacific Ocean. Regarding the relative importance of anthropic or natural drivers of such variation, we suggest that shifts in environmental conditions during the late Holocene, especially in the last 2000 years, such as the decrease in sea surface temperatures in the Strait of Magellan (Caniupán et al. 2014) and changes in marine productivity (Aracena et al. 2015), are likely key factors. Human impacts on this species such as its overexploitation is less probable, since in the study region, major fisheries were developed very recently.

It is also necessary to consider that the settlements of the Intermediate Period are located in the central sector of the Strait of Magellan and that the low presence of marine mammals, in comparison to birds and fish, may be due to the presence of seasonal hunting camps in other remote areas, for example, the western archipelagos where the reproductive colonies of pinnipeds are concentrated (Sielfeld 1983). In this way, demersal fishing could have been an activity that intensified in winter, as a measure of buffer subsistence due to the scarcity of other types of resources.

The aims of this paper were to evaluate the viability of the use of fish vertebrae as proxies for growth and seasonality studies of prehistoric fishing, given their abundance in the archaeological sites of marine hunter-fisher-gatherers in Patagonia. The results show that they have a significant potential for these studies, however it is important to emphasize that prior to the application of this technique and the exhaustive elaboration of a modern reference collection, it is 
necessary to test its feasibility in each species and that the hard body parts (e.g. vertebrae) display marks with a clear trend.

\section{Acknowledgements}

Funding for this research was provided by grants FONDECYT N³170733 and CONICYT-PAI $\mathrm{N}^{\mathrm{o}}$ 77170027. We are grateful for the collaboration of the Instituto de la Patagonia, Universidad de Magallanes, Flavia Morello and Fabiana Martin. We are also grateful to the laboratory Ethnologie préhistorique UMR 7041, Arscan (France), especially to Dominique Legoupil. Also to Consuelo Huidobro and Rocio Villar for their support in the initial analysis. Finally to IFREMER (France), for the technical support in data analysis and processing, to Chris Harrod for his important suggestions and English corrections, and to Jill Cucchi for copy-editing.

\section{References}

Antezana, T. 1999. Plankton of Southern Chilean fjords: trends and linkages. Scientia Marina 63:69-80.

Aracena, C., R. Kilian, C. B. Lange, S. Bertrand, F. Lamy, H. W. Arz, R. De Pol-Holz, O. Baeza, S. Pantoja, and C. Kissel. 2015. Holocene variations in productivity associated with changes in glacier activity and freshwater flux in the central basin of the Strait of Magellan. Palaeogeography, Palaeoclimatology, Palaeoecology 436:112-122.

Avilés, S., and M. Aguayo. 1979. Brótula. Salilota australis (Günther 1878). Teleostomi, Gadiformes, Moridae, Sinopsis 29 pp. Chile: Instituto de Fomento Pesquero (IFOP).

Béarez, P., F. Fuentes-Mucherl, S. Rebolledo, D. Salazar, and L. Olguín. 2016. A 7000 year old billfish fishery on the northern coast of Chile. Journal of Anthropological Archaeology 41:185195. 
Béarez, P., and L. Miranda. 2000. Análisis arqueo-ictioarqueológico del sector residencial del sitio arqueológico de Caral-Supe, costa central del Perú. Arqueología y Sociedad. Museo de Arqueología y Antropología 13:67-77.

Beamish, R. J. B, and G. A. Mcfarlane. 1983. The Forgotten Requirement for Age Validation in Fisheries Biology. Transactions of the American Fisheries Society 112(6):735-743.

Brett, J. R. 1971. Energetic responses of salmon to temperature. A study of some thermal relations in the physiology and freshwater ecology of sockeye salmon (Oncorhynchus nerka). American Zoologist 11:99-113.

Brett, J. R. 1979. Environmental factors and growth. In Fish physiology, ed. W.S. Hoar, D.J. Retaland J.R. Brett, Vol. 8, 599-675. London: Academic Press.

Caniupán, M., F. Lamy, C. B. Lange, J. Kaiser, R. Kilian, H. W. Arz, T. León, G. Mollenhauer, S. Sandoval, R. De Pol-Holz, et al. 2014. Holocene sea-surface temperature variability in the Chilean fjord region. Quaternary Research 82:342-353.

Cassia, M. C. 2006. Distribución y estructura poblacional de tres especies de peces pertenecientes al área austral : Micromesistius australis, Salilota australis y Dissostichus eleginoides. Ph.D. Thesis. Facultad de Ciencias Exactas y Naturales. Universidad Nacional del Mar del Plata, 170p. Cassia, M. C. and J. Hansen. 2005. Distribución estacional y estructura poblacional del bacalao austral (Pisces, Moridae, Salilota australis) en la zona económica exclusiva Argentina entre los $45^{\circ} \mathrm{S}$ y $56^{\circ} \mathrm{S}$ durante 1992 y 1993. Revista de Investigación de Desarrollo Pesquero 17:55-65.

Casteel, R. W. 1976. Fish remains in archaeology and pale-environmental studies. 1st. ed. New York: Academic press.

Chong Follert, L., F. Contreras, and J. C. Quiroz. 2017. Biología reproductiva y aspectos poblacionales de la brótula (Salilota australis) en la zona sur-austral de Chile: consideraciones para el manejo de la pesquería. Latin American Journal Aquatic Research 45(4):787-796. 
Desse, J., and N. Desse-Berset. 1992. Age et saison de mort des poissons : applications à l'archéologie. In Tissus Durs et Age Individuel des Vertébrés, ed. J. L. Baglinière, J. Castanet, F. Conand, F. and J. Meunier, 341-353. Paris: ORSTOM-INRA.

Emperaire, J., and A. Laming 1961. Les gisements des îles Englefield et Vivian. Journal de la Société des Américanistes 50:7-75.

Gaete, N., M. Sánchez, and L. Vargas. 1998. Caza, pesca y recolección durante el Arcaico en la costa del interfluvio Maule-Itata, Área extremo sur andina, Chile. Primer Seminario de Arqueología Zona Centro Sur de Chile, 7-23. Concepción, Chile: Universidad San Sebastián.

Gaete, N., X. Navarro, F. Constantinescu, C. Mera, D. Selles, M. E. Solari, M. L. Vargas, D. Oliva, and L. Durán. 2004. Una mirada al modo de vida canoero del mar interior desde Piedra Azul. Chungará 36 supl.: 333-346.

González, H., L. Castro, G. Daneri, J. Iriarte, N. Silva, F. Tapia, E. Teca, and C. Vargas. 2013. Land-ocean gradient in haline stratification and its effects on plankton dynamics and trophic carbon fluxes in Chilean Patagonian fjords $\left(47^{\circ}-50^{\circ} \mathrm{S}\right)$. Progress in Oceanography 119:32-47.

Guillaud, E., R. Elleboode, K. Mahé, and P. Béarez. 2017. Estimation of age, growth and fishing season of a Palaeolithic population of grayling (Thymallus thymallus) using scale analysis. International Journal of Osteoarchaeology 27(4):683-692.

Harada, N., U. Ninnemann, C.B., Lange, M. Marchant, M. Sato, N. Ahagon, and S. Pantoja. 2013. Deglacial-Holocene environmental changes at the Pacific entrance of the Strait of Magellan. Palaeogeography, Palaeoclimatology and Palaeoecology 375:125-135.

Iriarte, J. L., A. Kusch, J. Osses, and M. Ruiz. 2001. Phytoplankton biomass in the sub-Antarctic area of the Straits of Magellan $53^{\circ}$ S), Chile during spring-summer 1997/1998. Polar Biology 24:154-162. 
Iriarte, J. L., L. A. Cuevas, F. Cornejo, N. Silva, H. E. González, L. Castro, P. Montero, C. A. Vargas, and G. Daneri. 2018. Low spring primary production and microplankton carbon biomass in Sub-Antarctic Patagonian channels and fjords (50-53 $\left.{ }^{\circ} \mathrm{S}\right)$. Arctic, Antarctic, and Alpine Research 50:1. DOI: 10.1080/15230430.2018.1525186.

Kilian, R., O. Baeza, T. Steinke, M. Arévalo, C. Ríos, C. Schneider. 2007. Late Pleistocene to Holocene marine transgression and thermohaline control on sediment transport in the western Magellanes fjord system of Chile (53으. Quaternary International 161:90-107.

Kilian, R. and F. Lamy. 2012. A review of Glacial and Holocene paleoclimate records from southernmost Patagonia (49-55 S). Quaternary Science Reviews 53:1-23.

Kimura, D. K. 1980. Likelihood methods for the von Bertalanffy growth curve. Fishery Bulletin 77(4):765-776.

Lefèvre, C., and V. Laroulandie. 2014. Avian Skeletal Part Representation: A Case Study from Offing 2, A Hunter-Gatherer-Fisher Site in the Strait of Magellan (Chile). International Journal of Osteoarchaeology 24:256-264.

Legoupil, D. 1997. Bahía Colorada (île d'Englefield). Les premiers chasseurs de mammifères marins de Patagonie australe. Mémoires de l'A.D.P.F., Recherches sur les Civilisations, Paris. Legoupil, D., P. Béarez, C. Lefèvre, M. San Román and J. Torres. 2011a. Estrategias de subsistencia de cazadores recolectores de isla Dawson (estrecho de Magallanes) durante la segunda mitad del Holoceno: primeras aproximaciones. Magallania 39(2):153-164.

Legoupil, D., P. Béarez, S. Lepetz, M. San Roman and K. Salas. 2007. De la pesca a la caza : evolución económica del sitio Stuven 1, al sur del Golfo de Penas. In Arqueología de FuegoPatagonia. Levantando piedras, desenterrando huesos... y develando arcanos, 295-310. Punta Arenas, Chile: Ediciones CEQUA. 
Legoupil, D., M. Christensen, and F. Morello. 2011b. Una encrucijada de caminos: el poblamiento de la isla Dawson (Estrecho de Magallanes). Magallania 39(2):137-152.

Legoupil, D., J. Torres, P. Béarez, P Bertran, M, Christensen and Ch. Lefèvre. 2009. Le site de l'île Offing, Rapport de Mission 2009. Rapport de la Mission Archéologique de Patagonie (Ministère des Affaires Etrangères). Paris, France.

Mahé, K., R. Bellail, J. L. Dufour, A. Boiron-Leroy, J. Dimeet, E. Duhamel, R. Elleboode, J. Felix, P. Grellier, J. Huet, et al. 2009. Synthèse française des procédures d'estimation d'âge. Programme SIDEPECHE, Projet Système d'Informations Halieutiques Sous-Action Sclérochronologie. Vol 1. France : IFREMER. Accessed Decembre 9, 2019. https://archimer.ifremer.fr/doc/00000/7294/.

Mahé, K., F. Fave, and J. Couteau. 2011. TNPC User guide. France : IFREMER. Accessed Decembre 9, 2019. https://archimer.ifremer.fr/doc/00032/14288/

McCulloch, R. D., and S. Davies. 2001. Late-glacial and Holocene palaeoenvironmental change in the central Strait of Magellan, southern Patagonia. Palaeogeography, Palaeoclimatology, Palaeoecology 173:143-173.

Montecino, V., and C. Lange. 2009. The Humboldt Current System: Ecosystem components and processes, fisheries, and sediment studies. Progress in Oceanography 83(1):65-79.

Morello, F., J. Torres, I. Martínez, K. Rodriguez, M. Arroyo-Kalin, C. French, V. Sierpe, and M. San Román. 2012. Arqueología de la punta Santa Ana : reconstrucción de secuencias de ocupación de cazadores-recolectores marinos del estrecho de Magallanes, Patagonia Austral, Chile. Magallania 40(2):129-149.

Munita, D. 2017. Ocupaciones arqueológicas en el borde costero del Seno de Reloncaví, el caso de bahía Ilque. Memoria para optar al titulo de arqueólogo. Departamento de Antropología, Universidad de Chile, Santiago, Chile. 
Olguín, L. D. Salazar, and D. Jackson. 2014. Tempranas evidencias de navegación y caza de especies oceánicas en la costa pacífica de Sudamérica (Taltal, 7.000 años cal. a.p.). Chungará 46(2):177-192.

Ortiz-Troncoso, O. 1979. Punta Santa Ana et Bahía Buena : deux gisements sur une ancienne ligne de rivage dans le détroit de Magellan. Journal de la Société des Américanistes 56:133-204.

Paloheimo, J. E., and L. M. Dickie. 1966. Food et growth of fishes. II. Effects of food and temperature on the relation between metabolism and body weight. Journal of the Fisheries Research Board of Canada 23:869-908.

Pérez Comas, J. A. 1980. Distribución, aéreas de concentración y estructura de la población del Bacalao austral (Salilota australis, Günther, 1887) del Atlántico sudoccidental. Revista de investigación y desarrollo pesquero 2(2):22-37. Argentina.

Panfili, J., H. De Pontual, H. Troadec, and P. J. Wright. 2002. Manual of Fish Sclerochronology. $\begin{array}{lllll}\text { Brest, } & \text { France: } & \text { Ifremer. } & \text { Accessed }\end{array}$ https://archimer.ifremer.fr/doc/00017/12801/9742.pdf

Quiroz, D., M. Massone, and L. Contreras. 2000. Cazadores «talcahuanenses» en las costas de Arauco durante el Holoceno Medio. Perspectivas arqueológicas en Patagonia. In Actas de las IV Jornadas de Arqueología de la Patagonia, Río Gallegos, Universidad Nacional de la Patagonia. Vol. II: 621-633.

Quiroz, D., M. Massone, and M. Sánchez. 2001. La presencia de cazadores recolectores marítimos arcaicos en el Golfo de Arauco, sector La Obra, Coronel. Boletín de la Sociedad Chilena de Arqueología 32:50-56.

Quiroz, D., and M. Sánchez. 2000. Le-4: Pescadores en la costa de la Araucanía hace 2000 años. Museos 24:33-37. 
Rebolledo, S., P. Béarez B, D. Salazar, and F. Fuentes. 2016. Maritime fishing during the Middle Holocene in the hyperarid coast of the Atacama Desert. Quaternary International 391:3-11.

Reitz, E. J., C. F. T. Andrus, and D. H. Sandweiss. 2008. Ancient Fisheries and Marine Ecology of Coastal Perú. In Human Impacts on Ancient Marine Ecosystems: A Global Perspective, ed. C. Torben, C. Rick and J. M. Erlandson, 125-145, Berkeley: University of California Press.

Reitz, E. J. and D. H. Sandweiss. 2001. Environmental Change at Ostra Base Camp, a Peruvian Pre-ceramic Site. Journal of Archaeological Science 28:1085-1100.

Reyes, P., and M. Hüne. 2012. Peces del Sur de Chile. Santiago, Chile: Ocho Libros Editores.

Salazar, D., C. Arenas, P. Andrade, L. Olguín, J. Torres, C. Flores, G. Vargas, S. Rebolledo, C. Borie, C. Sandoval, et al. 2017. From the use of space to territorialisation during the Early Holocene in Taltal, coastal Atacama Desert, Chile. Quaternary International 473:225-241.

Salvatteci, R., D. Field, D. Gutiérrez, T. Baumgartner, V. Ferreira, L. Ortlieb, A. Sifeddine, D. Grados, and A. Bertrand. 2018. Multifarious anchovy and sardine regimes in the Humboldt Current System during the last 150 years. Global Change Biology 24(3):1055-1068.

Sandweiss, D. H., R. Shady Solís, M. E. Moseley, D. K. Keefer, and C. R. Ortloff. 2009. Environmental change and economic development in coastal Peru between 5,800 and 3,600 years ago. Proceedings of the National Academy of Sciences 106(5):1359-1363.

San Román, M. 2005. Nuevos hallazgos de sitios de cazadores recolectores marinos tempranos en isla Englefield, mar de Otway. Magallania 33(2):173-176.

San Román, M., O. Reyes, F. Morello, and J. Torres. 2016. Archaeology of Maritime Huntergatherers from Southernmost Patagonia, South America: Discussing Timing, Changes and Cultural Traditions during the Holocene. In Marine Ventures. Archaeological Perspectives on Human-Sea 
Relations, ed. H. B. Bjerck, H. Mjelva Breivik, S. E. Fretheim, E. L. Piana, A. M. Tivoli, A. F. J. Zangrando and B. Skar, 157-174. Sheffield: Equinox Publishing.

Scartascini, F. L., M. Saez, A., and V. Volpedo. 2015. Otoliths as a proxy for seasonality: The case of Micropogonias furnieri from the northern coast of San Matías Gulf, Río Negro, Patagonia, Argentina. Quaternary International 373(1):136-142.

Rojas, R., Y. Guerrero, and N. Silva. 2004. Atlas Oceanográfico de Chile, Volumen $2,50^{\circ}$ a $70^{\circ} \mathrm{S}$ - $50^{\circ}$ a $90^{\circ} \mathrm{W}$. Centro Nacional de Datos Oceanográficos. Servicio Hidrográfico y Oceanográfico de la Armada de Chile. Accessed Decembre 9, 2019. http://www.shoa.cl/n_cendhoc/productos/atlas2/tsm/parenas/tsmarenasmensual.htm

Sielfeld, W. 1983. Mamíferos Marinos de Chile. Santiago: Editorial Universidad de Chile.

Sielfeld, W., G. Guzmán, and N. Amado. 2006. Distribución de peces del litoral rocoso de los canales patagónicos occidentales (483’'S - 53³4’S). Anales Instituto Patagonia (Chile) 34:2132.Sievers, H. A. 2008. Temperature and salinity in the austral Chilean channels and fjords. In Progress in the oceanographic knowledge of Chilean interior waters, from Puerto Montt to Cape Horn, ed. N. Silva and S. Palma, 31-36. Valparaíso: Comité Oceanográfico Nacional - Pontificia Universidad Católica de Valparaíso.

Seguel, Z. 1998. El conchal Bellavista 1 y el poblamiento temprano en el sector litoral de la bahía de Concepción. In Actas ler Seminario de Arqueología, zona centro-sur de Chile, 25-40. Concepción, Chile: Universidad San Sebastián.

Torres, J. 2007. ¿Redes o líneas de pesca? El problema de la asignación morfofuncional de los pesos líticos y sus implicancias en las tácticas de pesca de los grupos del extremo austral. Magallania 35(1):53-70. 
Torres, J. 2016. La pêche chez les chasseurs-cueilleurs marins de la région du détroit de Magellan et des mers adjacentes, de l'Holocène moyen aux temps ethnographiques : rôle, technologie et stratégies saisonnières. Ph.D. Thesis, Université Paris 1-Panthéon Sorbonne.

Torres, J., C. Silva, and M. Lucero. 2007. El rol de la pesca en la intensificación de las ocupaciones costeras durante el Holoceno Medio-Tardío (Bahía de Concepción, Región del Bío-Bío, Chile). Magallania 35(1):71-93.

Torres, J., and J. Ruz. 2011. Pescadores de la Tradición Cultural Englefield. Datos preliminares en la zona del estrecho de Magallanes y mar de Otway XII Región de Magallanes, Chile. Magallania 39(2):165-176.

Uphoff, C. S., C. W. Schoenebeck, W. W. Hoback, K. D. Koupal, and K. L. Pope. 2013. Degreeday accumulation influences annual variability in growth of age-0 walleye. Fisheries Research 147:394-398.

Valdenegro, A., and N. Silva. 2003. Caracterización oceanográfica física y química de la zona de canales y fiordos australes de Chile entre el estrecho de Magallanes y cabo de Hornos (Cimar 3 fiordos). Ciencia y Tecnología del Mar 26(2):19-57.

Van Neer, W., S. Augustynen, and T. Linkowski. 1993. Daily growth increments on fish otoliths as seasonality indicators on archaeological sites: the tilapia from Late Palaeolithic Makhadma in Egypt. International Journal of Osteoarchaeology 3:241-248.

Van Neer, W., L. Lougas, and A. D. Rijnsdorp. 1999. Reconstructing Age Distribution, Season of Capture and Growth Rate of Fish from Archaeological Sites Based on Otoliths and Vertebrae. International Journal of Osteoarchaeology 9:116-130.

Vargas, L. 2008. Peces en Piedra Azul, algo más que huesos de peces. Memoria de Título de arqueólogo, Departamento de Antropología, Universidad de Chile, Santiago, Chile. 
Wöhler, O. C., M. C. Cassia, J. E. Hansen. 2004. Biología y pesquería del bacalao austral (Salilota australis). In El Mar Argentino y sus recursos pesqueros, ed. R. P. Sánchez and S. I. Bezzi, Tomo 4, Los peces marinos de interés pesquero. Caracterización biológica y evaluación del estado de explotación, 347-359. Mar del Plata: Publicaciones Especiales INIDEP.

Zangrando, A. F. 2009a. Historia evolutiva y subsistencia de cazadores-recolectores Marítimos de Tierra del Fuego. Buenos Aires: Sociedad Argentina de Antropología.

Zangrando, A. F. 2009b. Is fishing intensification a direct route to hunter-gatherer complexity? A case study from the Beagle Channel region (Tierra del Fuego, southern South America). World Archaeology 41(4):589-608. 